\title{
Assessment of Available Livestock Feed Resources in South Gondar Zone, Amhara National Regional State, Ethiopia
}

\author{
Tilahun Debela \\ Livestock Research Process, Pawe Agriculture Research Center, Pawe, Ethiopia
}

Email address:

tiladeb1953@gmail.com

\section{To cite this article:}

Tilahun Debela. Assessment of Available Livestock Feed Resources in South Gondar Zone, Amhara National Regional State, Ethiopia. American Journal of Agriculture and Forestry. Vol. 9, No. 4, 2021, pp. 269-275. doi: 10.11648/j.ajaf.20210904.24

Received: July 26, 2021; Accepted: August 9, 2021; Published: August 31, 2021

\begin{abstract}
The study was conducted in four districts of South Gonder Zone of the Amhara National Regional State which represent highland and mid-altitude agro-ecology of the zone. In the study districts the existing livestock feed types, sources and the total DM obtained from each feed type has not been yet well addressed. So the objective of the study was to identify the major types and sources of available feed resources of livestock production. Two hundred ten rural households from both agro-ecologies were interviewed with semi-structured questionnaire. A single-visit-multiplesubject survey was carried out. The major types of feeds available are crop residues, natural pasture, hay, indigenous fodder trees and improved forage crops and pasture which vary in season. The annual average maintenance DM requirement per household was higher $(\mathrm{p}<0.05)$ in mid-altitude $(10.47$ TDM $)$ than in the highland agro-ecology $(8.92$ TDM) districts. An average of 9.69 TDM of maintenance DM was produced per household from the major available feed resources, of which $62.08 \%, 12.24 \%$ and $12.19 \%$ was obtained from crop residues, conserved hay and grazing land, respectively. The average livestock population per household was 5.92 TLU and the average annual utilizable DM feed per household was 9.69 TDM. The study recommended that strategies like sustainable conservation of hay and crop residues during a surplus season, development of improved forages and proper storage and appropriate utilization of available feed resources are an option to mitigate feed shortage.
\end{abstract}

Keywords: Agro-ecology, Feed Resources, Livestock, Total Dry Matter

\section{Introduction}

Livestock are key assets in rural Ethiopia providing multiple economic, social, and risk management functions. Currently, livestock production accounts for about $12-16 \%$ of the GDP and about $16 \%$ of foreign earnings of Ethiopia [1]. Livestock is the primary source of livelihood to pastoralists living in the vast dry sub-humid, semi-arid and arid areas of the country [1]. In Ethiopia, livestock production is an important source of income and means of livelihood for farmers [2] and generates $>85 \%$ of the farm cash income [3]. Livestock are kept for production of replacement stock, source of food, draught power, transport, income generation, soil compaction for planting cereal crops and manure production for soil fertility management [1].

Natural pasture and crop residues are the major livestock feed resources in the highland of Ethiopia where all livestock depend on them. Agro-industrial by products such oil seed cakes, milling by products, molasses and improved forages usage is restricted to the emerging private dairy and fattening farms [4]. The most important factors that determine the productivity of livestock are the availability of feed resources and the nutritional quality of the available feeds. Shortage of livestock feeds both in quantity and quality, especially during the dry season is one of the major problems to low milk production in the country [5]. The role of natural pasture grazing as a major livestock feed resource is diminishing from time to time due to decline grazing land size [4]. The use of native hay is limited in coverage and it is better in terms of its feeding value than crop residues if timely cut, proper handling and storage measures are applied. Even during years of good rainy season, forage is not sufficient to feed livestock in the highlands for reasons associated with restricted grazing land and poor management [6]. 
The Amhara region has a large number of livestock that significantly contributes to Ethiopia's overall economic growth. One of the major constraints, which strongly limit the productivity of livestock sub-sector in the region, is unavailability of high quality and quantity feed. Like anywhere in the country, more than $90 \%$ of the livestock feed in the region is natural pasture and crop residues. These feedstuffs are grossly low in quantity and quality to sustain animal production [7].

South Gondar zone has a considerable potential and opportunities for development of livestock production both in feed resources and breed and is still one of the target zones identified for expansion of market-oriented smallholder dairy production in Amhara region [8]. The zone has a large number of livestock, favorable climatic condition and is a home of Fogera cattle which has a better meat and milk production potential and is suitable for market-oriented livestock production due to its access to market and presence of all-weather roads connecting with big towns such as Bahir Dar, Gondar, Dessie, Mekele and Metema and with Sudan. The establishment of an export abattoir at Bahir Dar town is also a very good opportunity for livestock farmers for better market and encourages livestock productivity through better feeding. However, there is scanty of information regarding the available feed resources in South Gondar Zone.

Few literatures at hand mainly focuses on the existing feed resources without quantifying the amount obtained from each feed type and without indicating their values on the bases of dry matter available which could satisfy the DM requirement of the livestock. So in order to attain improvement in animal production and productivity, an assessment should be done on the types and sources of livestock feed resources and total DM feed production of the area. Thus, on the basis of this background the current study was intended with the objectives to identify the major types and sources of available livestock feed resources and recommend possible intervention mechanisms in South Gondar zone.

\section{Research Methodology}

\subsection{Study Areas}

The study was conducted in South Gondar zone of the Amhara National Regional State. The South Gondar zone is located $660 \mathrm{~km}$ Northwestern of Addis Ababa. The geographic location of the zone lies between $11^{\circ} 02^{\prime}-12^{\circ} 33^{\prime}$ North latitude and $37^{\circ} 25^{\prime}-38^{\circ} 43^{\prime}$ East longitude. The zone is characterized agro-ecologically as highland (Dega) and mid altitude (Woina Dega) and the altitude ranges from 1500 to 3200 meters above sea level (m.a.s.l). The study area is generally characterized by its rugged topography from the place called Gunna Mountain $(4231 \mathrm{~m})$ to the mid altitude of Dera district at the Lake Tana border. The annual minimum and maximum temperature ranges from 17 to 27 degree Celsius, respectively. Rainfall distribution is largely monomodal from June to mid-September. The heaviest rain usually occurs during July and August, and the mean annual rainfall varies widely from $500 \mathrm{~mm}$ up to $1600 \mathrm{~mm}$ [8].

\subsection{Sampling Technique}

For this study Lay Gayint, Farta, East Estie and Dera districts were selected purposely in order to represent all agro-climatic areas of the zone. Lay Gayint and Farta represented the highlands with altitude ranging from 23003200 m.a.s.1. and East Estie and Dera from mid-altitude districts with altitude ranging from 1500-2300 m.a.s.l., then from the total Rural Kebeles (RKs) $10 \%$ of potential RKs were purposively selected; finally for this study 7 RKs from highland and 7 RKs from mid-altitude agro-ecological zone a total of $14 \mathrm{RKs}$ were selected. The criteria for selection was multifold vis livestock population, accessibility and experience of farmers keeping livestock were used as criteria to select RKs and farmers. From the selected RKs, households were selected randomly from comprehensive list of households available from RKs office and were 15 per RKs amounting to 210 households which currently own livestock were included in the whole study.

\subsection{Data Sources and Collection Methods}

Both primary and secondary sources were used to collect the data. Primary data were collected by interviewing selected livestock producers with the help of semi-structured questionnaire, Focus Group Discussion (FGD), Key Informant Interview (KII) and field visit. The semi-structured questionnaire were designed to obtain information based on farmers perception on socio- economic characteristics, land holding size and land use pattern, household herd size and composition, purpose of keeping livestock, management practices, animal health, seasonality of feed resources, livestock feeding, cropping system and constraints of the production. The questionnaire was first pre-tested before the commencement of the study. Key informant interviews were conducted with zonal and district livestock and fishery resource promotion agency experts and development agents, which can help for cross checking the interview of selected groups.

Field visits were made on randomly selected households and community owned resources i.e. appearance of animals, status of grazing lands, feeding and housing methods, water resources, ways of conserving forages in the form of hay and other relevant husbandry activities. Focus group discussion was made at each RK to clarify issues not well addressed during survey and to validate some information collected by individual interview. Key informant interviews were conducted with zonal and district livestock and fishery resource promotion agency experts and development agents.

\subsection{Data Analysis}

Primary data from surveyed households were organized and analyzed using statistical package for social science (SPSS version 20). Mean, percentage values and standard deviations of various parameters were compared between the two locations. 


\section{Results and Discussion}

\subsection{Socio-economic Characteristics of Farm Households}

\subsubsection{Demographic Characteristics}

The average family size of the respondents was 5.7 and 6.6 per household in the highland and mid-altitude agroecologies, respectively. The result was lesser than that of reported by [9]. in North Gondar which was 7. 23, while it was higher than the national average family size of rural areas (4.9) per household [10]. The majority (90\%) of the respondents were male household heads. The educational level of the respondents were $26.1 \%$ in the high land and $25.3 \%$ in the mid- altitude areas were illiterate, while 48.9 and $49.9 \%, 17.5$ and $21.1 \%$ and 7.5 and $6.1 \%$ had educational background for read and write, elementary school (1-8 grade) and secondary school and above in the high land and mid-altitude agro- ecology of the study areas, respectively.

\subsubsection{Land Holding Size and Allocation}

Land is one of the most important resources required for successful implementation of any agricultural farming activities. In the study districts, the average total land owned by the households was $1.93+0.12$ hectare. The average landholding of the respondents is higher than the average national landholding size $(0.96 \mathrm{ha} / \mathrm{hh})$ and Oromia region
$(1.15 \mathrm{ha} / \mathrm{hh})$ [10]. The result indicated that about $85 \%$ of the land was allocated for cultivation while the rest was allocated for private grazing land $(12 \%)$, fallow land $(1 \%)$ and the rest $(2 \%)$ of the land was for others such as plantation and homestead.

\subsubsection{Livestock Holding}

Each household owned varying proportion of cattle, sheep, goats and equines. The total livestock holdings per household were 5.65, 5.87, 6.16 and 5.92 TLU for Lay Gayint, Farta, East Estie and Dera districts, respectively (Table 2). Contrary to the current study, the overall average TLU of livestock per household in the study district is $7.97,0.74,0.46,0.78,1.44$, 0.8 and 0.07 for cattle, sheep, goats, donkeys, horses and mules, respectively in Meta Roba district, Oromia Region were reported [11]. The average holding of livestock per household were higher $(p<0.05)$ in mid- altitude $(6.04$ TLU) than in the high land agro-ecology (5.76 TLU). This may attributed due to more communal and private grazing land, need of cattle for draught power and crop land availability from which higher proportion of livestock feed is derived. Sheep holding per household in the high land area is significantly greater $(\mathrm{p}<$ 0.05 ) than in mid- altitude agro-ecologies. This may be due to the agro-climatic condition of the area, which is suitable to rear sheep than others and NGOs working in these districts provide sheep to ensure food security.

Table 1. Mean Land holding and its distribution per household in the study districts.

\begin{tabular}{|c|c|c|c|c|c|c|c|}
\hline Variable & $\begin{array}{l}\text { Lay Gayint } \\
\text { Mean+SE } \\
\mathrm{N}=\mathbf{4 5}\end{array}$ & $\begin{array}{l}\text { Farta } \\
\text { Mean+SE } \\
\mathbf{N}=\mathbf{6 0} \\
\end{array}$ & $\begin{array}{l}\text { Average } \\
\text { Mean+SE } \\
\mathbf{N}=\mathbf{1 0 5} \\
\end{array}$ & $\begin{array}{l}\text { East Estie } \\
\text { Mean+SE } \\
N=60\end{array}$ & $\begin{array}{l}\text { Dera } \\
\text { Mean+SE } \\
\mathbf{N}=\mathbf{4 5} \\
\end{array}$ & $\begin{array}{l}\text { Average } \\
\text { Mean+SE } \\
\mathbf{N}=\mathbf{1 0 5} \\
\end{array}$ & $\begin{array}{l}\text { Overall } \\
\text { Mean+SE } \\
\mathbf{N}=\mathbf{2 1 0} \\
\end{array}$ \\
\hline Total land (ha) & $1.62+0.10$ & $1.84+0.10$ & $1.73+0.08$ & $2.03+0.13$ & $2.24+0.10$ & $2.14+0.08$ & $1.93+0.12$ \\
\hline Crop land (ha) & $1.46+0.09$ & $1.56+0.08$ & $1.51+0.04$ & $1.73+0.09$ & $1.81+0.08$ & $1.77+0.03$ & $1.64+0.07$ \\
\hline Grazing land (ha) & $0.12+0.02$ & $0.2+0.03$ & $0.16+0.03$ & $0.25+0.03$ & $0.34+0.04$ & $0.03+0.04$ & $0.23+0.04$ \\
\hline Fallow land (ha) & $0.02+0.01$ & $0.025+0.01$ & $0.023+0.11$ & $0.01+0.01$ & $0.03+0.01$ & $0.02+0.007$ & $0.021+0.004$ \\
\hline Other (ha) & $0.02+0.01$ & $0.05+0.02$ & $0.035+0.09$ & $0.04+0.01$ & $0.06+0.02$ & $0.05+0.007$ & $0.04+0.007$ \\
\hline
\end{tabular}

$\mathrm{N}=$ number of respondents; $\mathrm{SE}=$ standard error.

Goat holding per household in mid- altitude is significantly greater $(p<0.05)$ than the high land agro-ecology which may be due to the suitability of the area and availability of browse for the goats' feed. Out of the total cattle, oxen are dominant in all districts. This is because of the contribution of oxen to crop production as source of draught power and during threshing. Most of the cattle reared are indigenous. Crossbred cattle comprise $5.2 \%$ of the total cattle and were distributed both in the highland and mid altitude district.

\subsection{Feed Resources Availability}

The feed resources available to livestock includes native pasture, crop residues, crop aftermath, conserved hay, indigenous fodder Trees/shrubs, supplements of agroindustrial by-products and to some extent cultivated forage and pasture crops. The availability of these feed resources varied depending on season and agro-ecological zones with respect to quantity. The types of feed resources were not significantly different between highland and mid altitude agro-ecological zones. This may be due to in both agroecologies; mixed crop-livestock production system is more practiced by the farming community.

\subsubsection{Natural Pastures}

Smallholder farmers in each district traditionally use naturally occurring grasses, legumes herbs, and shrubs as the primary feed for their animals. They are used either direct grazing or browsing by livestock or can be harvested and conserved as hay for use during period of scarcity. Pasture land management is traditional and an effort done by farmers for improving the pasture land was limited. About 12\% (25 farmers) of the total respondent farmers were practicing proper management and improvement of natural pasture like manure application, weed control, area closure and over sowing with legume and grass to improve its productivity.

The average dry matter yield obtained from natural pasture lands ranged from 1.7 to 1.9 tons of $\mathrm{DM} / \mathrm{ha}$, in which in the highland 1.77 and in the mid- altitude areas was found to be 1.84 tons/ha. The result obtained in this investigation is 
higher than that of described in other findings $[12,13]$ which is 1.5 tones DM/ha.

Table 2. Mean livestock holding and Composition of sample households across the study districts.

\begin{tabular}{lllllc}
\hline Variable & $\begin{array}{l}\text { Lay Gayint } \\
\text { Mean+SE } \mathbf{N = 4 5}\end{array}$ & $\begin{array}{l}\text { Farta Mean+SE } \\
\mathbf{N = 6 0}\end{array}$ & $\begin{array}{l}\text { East Estie } \\
\text { Mean+SE } \mathbf{~ N = 6 0}\end{array}$ & $\begin{array}{l}\text { Dera Mean+SE } \\
\mathbf{N = 4 5}\end{array}$ & $\begin{array}{l}\text { Overall } \\
\text { Mean+SE } \mathbf{N = 2 1 0}\end{array}$ \\
\hline Livestock (TLU) & $5.65+0.31$ & $5.87+0.34$ & $6.16+0.29$ & $5.92+0.33$ & $5.9+0.31$ \\
Cattle (TLU) & $3.57+0.30$ & $3.78+0.29$ & $4.06+0.31$ & $4.34+0.40$ & 100 \\
Sheep (TLU) & $0.64+0.30$ & $0.62+0.32$ & $0.52+0.33$ & $0.44+0.29$ & $0.94+0.30$ \\
Goat (TLU) & $0.29+0.36$ & $0.31+0.19$ & $0.41+0.26$ & $0.38+0.23$ & $0.35+0.29$ \\
Donkey (TLU) & $0.30+0.10$ & $0.25+0.078$ & $0.35+0.076$ & $0.30+0.08$ & $0.35+0.20$ \\
Horse (TLU) & $0.64+0.10$ & $0.56+0.08$ & $0.40+0.066$ & $0.32+0.07$ & $0.3+0.29$ \\
Mule (TLU) & $0.21+0.06$ & $0.35+0.056$ & $0.42+0.07$ & $0.14+0.05$ & $0.48+0.09$ \\
\hline
\end{tabular}

$\mathrm{N}=$ number of respondents; $\mathrm{SE}=$ standard error; $\mathrm{TLU}=$ tropical livestock unit.

The result obtained from mid-altitude is significantly greater $(\mathrm{P}<0.05)$ than high land districts. This was probably due to the large area of communal grazing land available per household and also the composition of grass in grazing lands was higher than legumes in the mid altitude as compared to high land districts.

The other reason may be in the high land areas most grazing lands are found on hillsides and mountains which are unproductive. The average holding of grazing land from communal grazing was 0.59 ha. in the highland and 0.73 ha in the mid- altitude area. From field observation, land use pattern of DOoARD (District Office of Agriculture and Rural Development) and interviewing of farmers the contribution of natural pasture land coverage in both agro- ecologies were declining from year to year due to the expansion of cropping lands, population growth and increased livestock population per unit area was the most important factor contributing.

During the open-ended discussion with key informants and community representatives, the participants revealed that the common problems that hinder the development and productivity of natural pasture lands in their areas are expansion of crop land, invasion of grazing land by weed and bush, over grazing, over stocking, soil degradation in steep areas, no way to improve the natural grazing land, communal grazing lands have no ownership restriction and responsibility compare to private grazing land and Prolonged drought and disappearance of palatable species (especially in Lay Gayint) in their order of important.

Table 3. Feed resources and animal feed dry matter supply per household in the study districts.

\begin{tabular}{|c|c|c|c|c|c|c|c|c|c|c|}
\hline \multirow{3}{*}{ Feed available } & \multicolumn{8}{|c|}{ Districts } & \multirow{3}{*}{$\begin{array}{l}\begin{array}{l}\text { Overall } \\
(N=\mathbf{2 1 0})\end{array} \\
\text { TDM } \\
\end{array}$} & \multirow{3}{*}{$\begin{array}{l}\text { Composition } \\
(\%) \\
\% \\
\end{array}$} \\
\hline & \multicolumn{2}{|c|}{ Lay Gayint $N=45$} & \multicolumn{2}{|c|}{ Farta $N=60$} & \multicolumn{2}{|c|}{ East Estie $N=60$} & \multicolumn{2}{|c|}{ Dera $N=45$} & & \\
\hline & TDM & $\%$ & TDM & $\%$ & TDM & $\%$ & TDM & $\%$ & & \\
\hline Grazing land & 0.91 & 10.9 & 1.18 & 12.4 & 1.43 & 13.19 & 1.24 & 12.28 & 1.19 & 12.19 \\
\hline Crop residue & 5.68 & 68.1 & 5.87 & 61.72 & 6.33 & 58.4 & 6.05 & 59.9 & 5.98 & 62.03 \\
\hline Crop aftermath & 0.73 & 8.8 & 0.78 & 8.2 & 0.87 & 8.02 & 0.91 & 9.0 & 0.82 & 8.51 \\
\hline Conserved hay & 0.64 & 7.7 & 1.10 & 11.56 & 1.76 & 16.23 & 1.36 & 13.47 & 1.21 & 12.24 \\
\hline Fodder trees & 0 & 0 & 0.026 & 0.27 & 0.014 & 0.12 & 0.11 & 1.09 & 0.04 & 0.37 \\
\hline Fallow land & 0.014 & 0.2 & 0.003 & 0.03 & 0.006 & 0.05 & 0.02 & 0.20 & 0.01 & 0.12 \\
\hline Irrigation by-products & 0.1 & 1.2 & 0.30 & 3.15 & 0.26 & 2.4 & 0.30 & 2.97 & 0.24 & 2.43 \\
\hline Agro-industrial by-prod. & - & - & 0.014 & 0.15 & 0.004 & 0.03 & 0.01 & 0.10 & 0.01 & 0.07 \\
\hline Total supply & 8.33 & 100 & 9.51 & 100 & 10.84 & 100 & 10.09 & 100 & 9.69 & 100 \\
\hline
\end{tabular}

$\mathrm{N}=$ number of respondent; TDM= ton dry matter.

\subsubsection{Crop Residues}

Crop residues are the basal feed for a large proportion of livestock in the study areas. The major crop residues used as livestock feed include cereal straw (e.g. teff, wheat, barley, Finger millet, rice and oat), maize and sorghum stover, pulse straw (e.g. faba bean, field pea, chick peas, grass pea and lentils), and oil crop straws such as linseed straw are used. Maize and sorghum stover are generally less important as compared to cereal and pulse straw. Crop residues are mainly offered to animals during period of January to July. Draught oxen, lactating cows, fattening animals and weak/sick animals are the primary animals to be fed with the best available crop residues throughout the year.

The major cereal crop residues are stacked after threshing under a roof shade made of grass and wood which can protect against rainfall and direct sun exposure, around homesteads and covered with plastic sheets, to keep out rain and inside their house and on trees. The average utilizable DM yields of crop residues per household were 5.78 and 6.19 tons of DM/ annum by using 10\% loss rate [13], for high land and mid-altitude areas, respectively (Table 3). The crop residues produced in mid-altitude areas are significantly higher $(\mathrm{P}<0.05)$ than high land districts.

High DM production of crop residues produced in midaltitude was probably due to the type of crop grown such as finger millet, maize and rice, which have a multiplier larger than most crops in high land. The other reason may be the land possessed by individual households is larger which was reflected on the size of cultivated land. Hence, resulting in 
higher crop residues. In addition, in these districts there is a high experience of using chemical fertilizer for cultivating land as compared to the highland districts. The total contribution of crop residues to the total available DM was $62.03 \%$. This is less than the finding of [14] in Burie district which was $75.83 \%$ and greater than that reported by [9] in North Gondar and [15] in Amhara region that was 46.4 and $35.31 \%$, respectively.

\subsubsection{Crop Aftermath Grazing}

Stubble grazing was available after the harvests of cereal crops from late November to late February. Stubble grazing is accessible to all the community in the study area so that all livestock classes in the locality were able to graze without any restriction. The main cereal crops that were used as stubble grazing were wheat, barley, Finger millet, teff, rice, Oat, maize and sorghum. Pulse and oil crops aftermath also used for grazing after crop harvest. In addition to the stumps of the ripe crop and some straw, the stubbles also contain valuable feed in the form of fallen grain lost in the harvesting process and some pick weeds and other green materials.

\subsubsection{Conserved Hay}

In the study areas, hay is prepared from mid-October to end of November each year. Hay production is widely practiced in all the study districts, where feed shortage is sever and most land is allocated for crop production. Hay is stored by creating hay stalk close to where the hay would be required. Out of 210 respondent farmers in the study districts $46(22 \%)$ stored hay in a roof shade outside their home and the rest $164(78 \%)$ respondents store their hay outside the house by creating hay stacks. Stacks are covered by plastic sheet to protect the hay from rain and sun. In the highland zone of the study area preserving of forage for future use in the form of standing hay is common in communal grazing lands. In this process the grass is allowed to dry at the onset of the dry season in the place where it was grown. Prior to standing hay making livestock are withdrawn from the communal grazing lands and are not allowed back until the dry season when the standing hay is to be grazed. Standing hay is the main fed to draught oxen and lactating animals starting from January up to June months or cut and carry for their animals.

The mean private grazing land owned by the respondents was $0.12,0.2,0.25$ and 0.34 hectares per household for Lay Gayint, Farta, east Estie and Dera districts, respectively. The estimated hay DM production per household was 0.64, 1.10, 1.76 and 1.36 tons for Lay Gayint, Farta, East Estie and Dera districts, respectively. The productivity of grazing land in the study area was 4.33, 5.0, 5.04 and 5.10 tons per hectare per year. The finding in this study was higher than the result obtained from Adaa Liben district which described that annual average primary production of $2 \mathrm{t} \mathrm{DM} / \mathrm{ha}$ for the whole grazing areas containing poorly managed and overgrazed unimproved pastures [16] and comparable in seasonally waterlogged fertile areas, 4-6 tons of dry matter per ha [17].

The higher DM yield per hectare for Farta and Dera was that the private grazing land has better management like application of manure, over sowing with improved forage species, removal of unpalatable weeds and conservation practices in the form of hay and protect from animals for a limited period of time. The total contribution of hay to the total available DM was $12.24 \%$. The most naturally grown forage crops suitable for grazing and hay making in all districts are: Serdo (Andropogon nlemfuessis), Gaja (Andropogon abyssinicus), Muja (Snowdenia polystachya), Magete (Trifollum rueppellianum Fresen), Asendabo (Phalaris paradosa), Gecha (Typerus rigidisolius) and Sendedo (Setariau pumila).

\subsubsection{Indigenous Fodder Trees}

Fodder trees and shrubs come to be important source of energy and protein to keep the animal's body healthy, improve growth rate and even increase milk and meat production. Livestock in the study area would consume many different parts of trees and shrubs: leaves, young shoots, pods and fruit. Farmers in the mid-altitude agro-ecology zone use leaves and pods from naturally occurring fodder trees and shrubs as a dry season feed supplement for their animals. During the dry period trees and shrubs remain green for a longer period than grass because of their deeper rooting system. In the uncontrolled access of animals to fodder trees the farmers cut the side branch of the tree and chops to provide to animals. Some fodder trees are cut and wilted by farmers for some hours which make the fodder more palatable to stock. Indigenous fodder trees and shrubs grown and used as feed for animals are: Bamba (Ficus sycomorus), Warja/Shola (Ficus sur), Wanza (Corida Africana), Chibiha (Ficus thonningii), Girar (Acacia abyssinica), Lenkoata (Grewia ferruginea), Abalo (Jerminalia browni) and Atat (Maytenus arbutifolia).

\subsubsection{Agro-industrial By-Products}

Agro-industrial by-products in the study areas are commonly found from small-scale oil seed processing plants, grain milling and other agro-industrial processing plants. They are important source of relatively high quality feed mostly in pre-urban and urban areas where the resources are available on the market. Agro-industries are not well developed in the study areas, despite there were high potential areas for many agricultural resources to be used as raw materials for many agro-industries. The major agroindustrial by-products of importance available are rice and oat bran, oil seed cakes, and pulse hulls which are used as animal feed. These by-products are usually mixed with residues of home prepared drinks (Atela) and fed to animals. They are also mixed with water and salt.

\subsubsection{Improved Forage and Pasture Crops}

Many improved/cultivated forage and pasture crops have been introduced and demonstrated in the study districts by OoARD (Office of Agriculture and Rural Development) and other NGOs (Non-Governmental Organizations) like GTZ, NLDP and World vision. Forage species suitable for local agro-climatic conditions and high requirements of the 
community for fodder and other uses are: from tree legumes, Leucanea, Sesbania, Tree lucern, Pigeon pea and Acacia species. From grasses: Rhodes grass, Napier grass, Oats, Phalaris and Setaria. From herbaceous legumes: Desmodium, Vetch, Lablab, Cow pea, Siratero and Stylo are forage crops which have been grown. In the study area most improved forage and pasture crops are established in the back yards, fence lines, on conservation structures, under sowing into other annual or perennial crops.

The contribution of cultivated forage and pasture crops to the diet of farm animals was insignificant. In spite of many years of work on improved forage technologies by OoARD and NGOs, the adoption of smallholder farmers was very low. Overall, from the surveyed the possible reasons for the low adoption of improved forage technologies by smallholder farmers were, $53 \%$ of the respondents says low level of awareness about the production and importance of cultivated forage, $26 \%$ lack of suitable forage seeds and planting materials, $15 \%$ lack of adequate extension service and the rest $6 \%$ competition of forage production for resources (land, labor, and possibly other inputs) with crop production.

\section{Conclusions and Recommendations}

From this study it can be conclude that the contribution of the cereal crops in providing crop residues to the livestock feed was high which amounted to $62 \%$ of the total livestock feed available in the areas. To utilize the bulk amount of crop-residues more efficiently, alternative ways are need to improve utilization efficiency of the residue. Among which, urea treatment, feeding of residue by mixing with green forage and feed supplement should be enhanced.

Moreover, to increase the productivity of communal grazing land which is found in large coverage especially in mid altitude agro-ecology, efficient grazing land management systems should be deliberated. Among which, adjusting stocking rate, use of rotational grazing, removal of unpalatable and noxious weeds, harvesting or utilizing at optimum biomass production and at acceptable forage quality should be implemented.

Cultivated forages are not yet adopted and developed by the farming community in the study area due to small land holding, insufficient knowledge, inadequate extension service and low economic incentive. So research and development efforts should have to identify high yielding and better quality improved forages that are adaptable to various agroecologies and production systems of the area and find other options to increase the adoption rate of farmers for improved forage and pasture crops production and utilization.

Nowadays most of the farmers' in the mid altitude agroclimatic area prefer chebiha (Ficus thonningii) as important energy and protein supplement feed to improve productivity of their animals during the dry season compared to other naturally growing fodder trees and shrubs, so for the better use of the plant and further intervention the important issues to be recovered are its biomass yield at different age and time of cutting and the digestibility of the plant material.

\section{References}

[1] Bewket W, Radeny M, and Mungai C., 2015. Agricultural Adaptation and Institutional Responses to Climate Change Vulnerability in Ethiopia. CCAFS Working Paper no. 106. CGIAR Research Program on Climate Change, Agriculture and Food Security (CCAFS). Copenhagen, Denmark. Available online at: www.ccafs.cgiar.org

[2] Dereje T, Mengistu U, Getachew A and Yoseph M 2014: Flock structure, level of production, and marketing of three Ethiopian goat types kept under different production systems. Livestock Research for Rural Development 26 (5) 2014.

[3] Yeshitila, A., 2008. Efficiency of livestock feed resources utilization and forage development in Alaba Woreda, Southern Ethiopia. MSc. Thesis, HU, Dire Dawa Ethiopia. 128p.

[4] Yayneshet Tesfaye, 2010. Feed Resources Availability in Tigray Region, northern Ethiopia, for Production of Export Quality Meat and Livestock. Ethiopia Sanitary \& Phytosanitary Standards and Livestock \& Meat Marketing Program (SPS-LMM), Texas A\&M University System.

[5] Zewdie Wondatir, 2010. Livestock production systems in relation with feed availability in the highlands and central rift valley of Ethiopia. An MSc thesis presented to HU.

[6] Melese, G., Berhan, T. and Mengistu, U., 2014. Effect of Supplementation with Non-Conventional Feeds on Feed Intake and Body Weight Change of Washera Sheep Fed Urea Treated Finger Millet Straw. Greener Journal of Agricultural Sciences, 4 (2): 067- 074.

[7] BoARD (Bureau of Agriculture and Rural Development), 2018. Rural Household Socioeconomic Baseline Survey. Amhara Region Bahir Dar, Ethiopia.

[8] OoARD (Office of Agriculture and Rural Development), 2018. Documentation of Planning and Programming Department of South Gondar zone OoARD. Debra Tabor, Ethiopia.

[9] Sisay Amare, 2006. Livestock Production Systems and Available Feed Resources in Different Agro-Ecologies of North Gondar zone, Ethiopia. MSc Thesis, Alemaya University.

[10] CSA (Central Statistical Agency), 2011. Ethiopia Demographic and health Survey. 55p.

[11] Endale Yadessa, 2015. Assessment of Feed Resources and Determination of Mineral Status of Livestock Feed in Meta Robi District, West Shewa Zone, Oromia Regional State, Ethiopia MSc. Thesis. Ambo University, Ambo. 2015. Ethiopia.

[12] MOA (Ministry of Agriculture). 1984. General Agricultural Survey. Preliminary Report 1983/84. Vol. II MOA, Addis Ababa, Ethiopia.

[13] Adugna Tolera, and A. N. Said, 1994. Assessment of Feed Resources in Welayta Sodo, Eth. J. Agric. Sci., Vol, 14 (1/2) p 69-87.

[14] Shitahun Mulu, 2009. Feed Resources Availability, cattle fattening practices and marketing system in Burie Woreda. Amhara Region Ethiopia. MSc Thesis. Mekelle University. 
[15] Firew Tegene and Getnet Asefa, 2009. Feed resource assessment in Amhara National Regional state, Bahir Dar Ethiopia.

[16] ESAP (Ethiopian Society of Animal Production), 2009. Commercialization of Livestock Agriculture in Ethiopia. Tamrat Degefa and Fekede Feyissa (Eds). Proceedings of the 16th Annual conference of the ESAP held in Addis Ababa, Ethiopia, October 8 to 10, 2008.

[17] Alemayehu Mengistu, 1987. Feed Resources in Ethiopia. 42p, Proceedings of the Second National Livestock Improvement Conference. Addis Ababa, Ethiopia, 11-13 February 1987. Institute of Agricultural Research. 